E-ISSN: $2502-6674$

P-ISSN: 2502-6666

http://ojs.uho.ac.id/index.php/p_sejarah_uho

\title{
SEJARAH PASAR SENTRAL WAKURU KECAMATAN TONGKUNO KABUPATEN MUNA (1977-2017) ${ }^{1}$
}

\author{
HISTORY OF THE CENTRAL MARKET OF WAKURU KECAMATAN \\ TUNKUNO MUNA DISTRICT (1977-2017) \\ Ramadan Uga ${ }^{2}$ \\ e-mail: ramadan_uga77@gmail.com
}

\author{
Mursidin $\mathbf{T}^{3}$ \\ e-mail: mursidint@uho.ac.id
}

\section{${ }^{1)}$ Hasil Penelitian Tahun 2018, ${ }^{2)}$ Alumni Jurusan Pendidikan Sejarah, ${ }^{3)}$ Dosen FKIP UHO}

\begin{abstract}
ABSTRAK: Permasalahan pokok dalam penelitian ini adalah 1) Bagaimana latar belakang terbentuknya Pasar Sentral Wakuru. 2) Apa saja fungsi Pasar Sentral Wakuru bagi kehidupan masyarakat Wakuru Kecamatan Tongkuno Kabupaten Muna. 3) Bagaimana perkembangan Pasar Sentral Wakuru Kecamatan Tongkuno Kabupaten Muna (1977-2017). Jenis penelitian ini adalah Penelitian Sejarah yang bersifat deskriptif kualitatif. Pendekatan yang digunakan dalam penelitian ini adalah Pendekatan Historis. Sumber data penelitian ini informan dan studi kepustakaan. Metode yang digunakan dalam penelitian ini adalah metode sejarah yang terdiri dari heuristic, verifikasi dan historiografi; Hasil penelitian menunjukkan bahwa: (1) Pasar Sentral Wakuru Kecamatan Tongkuno Kabupaten Muna dibangun pada tahun 1977 yang dilatarbelakangi oleh inisiatif beberapa warga masyarakat Wakuru yang bertempat tinggal Lemoambo/kampung lama dengan membuka pasar darurat pada tahun 1977 melalui persetujuan pemerintah pada waktu itu La Mbolo Lega menjadi kepala desa pasar tersebut dipindahkan di Desa Fongkainiua Kecamatan Tongkuno Kabupaten Muna. (2) Fungsi Pasar Wakuru merupakan wadah atau arena saling bertemunya parah penjual dan pembeli. Dalam bentuk yang sederhana, pasar berperan penting dalam memenuhi berbagai kebutuhan konsumen seperti masyarakat lainnya. masyarakat Wakuru Kecamatan Tongkuno mempunyai kebutuhan yang bersifat primer atau pokok dan sekunder atau kebutuhan tambahan. Sedangkan kebutuhan sekunder merupakan Perlengkapan dari kebutuhan pokok, yang dimaksud kebutuhan sekunder disini adalah barang barang elektronik. (3) pada tahun 1977 Pasar Wakuru dibangun awalnya 40 x 40 meter terdiri dari 50 petak kios. Pada tahun 1979 Pasar Wakuru mulai berkembang yang akhirnya direhab menjadi permanen karena dengan adanya partisipasi dan kerja sama masayarakat setempat dan membuat pondasi dengan susunan batu bata karena penjualan mulai berkembang.
\end{abstract}

Kata Kunci: Sejarah, Fungsi, Perkembangan, Pasar

ABSTRACT: The main problems in this study are 1) What is the background of the formation of the Central Market of Wakuru. 2) What are the functions of the Wakuru Central Market for the life of the Wakuru community, Tongkuno District, Muna Regency. 3) How is the development of the Central Wakuru Market Tongkuno District Muna District (1977-2017). This type of research is a qualitative descriptive research history. The approach used in this study is the Historical Approach. The data source of this research are informants and literature studies. The method used in this study is the historical method which consists of heuristics, verification and historiography; The results showed that: (1) Wakuru Central Market, Tongkuno Subdistrict, Muna Regency was built in 1977 which was motivated by the initiative of several Wakuru residents who lived in Lemoambo / old villages by opening an emergency market in 1977 through government approval at that time La Mbolo Lega being the head of the market village was moved in Fongkainiua Village, Tongkuno District, Muna Regency. (2) The function of the Wakuru Market is a place where the sellers and buyers meet severely. In its simple form, the market plays an important role in meeting the various needs of consumers like other communities. Wakuru community of Tongkuno District has primary or primary and secondary needs or additional needs. While secondary needs are equipment of basic needs, what is meant by secondary needs here are electronic goods. (3) in 1977 Wakuru Market was built initially 40 x 40 meters consisting of 50 kiosks. In 1979 the Wakuru Market began to develop which was eventually rehabilitated to become permanent due to the participation and cooperation of the local community and to create a foundation with a brick arrangement as sales began to develop.

Keywords: History, Function, Development, Market 
E-ISSN: $2502-6674$

P-ISSN: 2502-6666

http://ojs.uho.ac.id/index.php/p_sejarah_uho

\section{PENDAHULUAN}

Upaya manusia dimana memenuhi kebutuhannya sudah berlangsung sejak manusia itu ada. Salah satu kegiatan manusia dalam memenuhi kebutuhan tersebut adalah memerlukan adanya pasar sebagai sarana pendukungnya. Sebelum terbentuknya pasar, manusia sudah terlebih dahulu mengenal yang namanya bercocok tanam. Dengan dikenalkan kegiatan bercocok tanam maka dapat diperoleh sedikit gambaran mengenai pola-pola tempat tinggal kegiatan perekonomian pada masa bercocok tanam tersebut. Hasil dari kegiatan itu sudah diperdagangkan pula secara barter (tukar-menukar barang). Barang-barang yang dipertukaran sudah diangkut dalam jarak yang jauh melalui sungai, laut dan darat. Barang yang dipertukarkan bukan saja hasil-hasil dari aktivitas di luar kegiatan bercocok tanam seperti gerabah, anyaman, dan alat-alat bekerja tetapi juga hasi-hasil pertanian/ cocok tanam seperti keladi (talas), ubi, sukun, pisang, buah kelapa, durian, salak, rambutan dan duku. R.P. Suyono dalam Leirissa (1996:7).

Melakukan kegiatan transaksi jual beli antara produsen dan konsumen pada dasarnya dapat terjadi dimana saja dan tidak harus dilakukan di tempat-tempat atau bangunan tertentu. Pada zaman dahulu misalnya, tempat pertemuan antara penjual dan pembeli tidak diperlengkapi dengan bangunan-bangunan permanen yang kokoh, tempat pertemuan itu dilakukan tidak secara tetap melainkan berpindah-pindah sesuai dengan kebutuhan dan kepentingan masyarakat. Akan tetapi dalam perkembangan selanjutnya pengertian pasar lebih dipahami sebagai suatu kegiatan yang melibatkan banyak orang dan dilakukan pada tempat tertentu yang bersifat permanen dan dilakukan setiap hari.

Keberadaan pasar pada hakekatnya bertujuan untuk memberikan pelayanan kepada masyarakat agar bisa memenuhi berbagai keinginan dan kebutuhan hidup sehari-hari (Soekarno dan Yustan Azidin, 1990:1) dibutuhkan bagi kelangsungan hidup sehari-hari. Pada perkembangan sekarang ini pasar tidak hanya berfungsi sebagai sarana pemenuhan kebutuhan hidup sehari-hari (keperluan akan makanan dan pakaian), namun juga menawarkan benda-benda lain disamping kebutuhan pokok tersebut. Menyadari pentingnya peranan pasar, maka kini hampir setiap kelompok masyarakat bahkan di desa terpencil sekalipun memiliki pasar.

Sebagai, pasar dengan segala perangkat yang ada di dalamnya secara tidak langsung bagi masyarakat sekitarnya. Hal ini menunjukkan bahwa bukan hanya peranan ekonomi tetapi juga peranan kebudayaan terhadap masyarakat di sekitarnya cukup besar Syarifuddin (1990:1-2). Dalam interaksi yang terjadi di pasar dipengaruhi pula oleh pengetahuan kebudayaan yang dipunyai oleh setiap individu atau kelompok masyarakat. Sedangkan pengetahuan kebudayaan merupakan kompleks ide, nilai serta gagasan utama yang menjadi sumber dan tolak ukur bagi setiap individu dalam bertingkahlaku (Soekarno dan Yustan Azidin, (1990: 2). Lebih lanjut Harsono (1995: 2) pasar merupakan pusat kegiatan jual beli, itu biasanya terletak ditempat yang mudah didatangi dari berbagai arah, berlangsung pada waktu-waktu tertentu dan, mengutamakan benda-benda keperluan hidup sehari-hari untuk keluarga

Perkembangan kehidupan manusia pada masa lampau, masa sekarang, dan masa yang akan datang selalu diwarnai oleh berbagai kegiatan pembangunanyang berjalan terus menerus, yang senantiasa mengalami perubahan dan perkembangan dari waktu kewaktu. Perubahan ini sangat membutukan hadirnya suatu bidang ilmu yang khusus mengkaji tentang perubahan dan perkembangan manusia pada setiap kurun waktu.

Kehadiran ilmu sejarah sangat penting artinya dengan sebab mempelajari sejarah berarti kita mengetahui lebih jauh dari perkembangan umat manusia dimuka bumi ini beserta segala kejadianya termaksut perkembangan seluruh aktivitasya yang akan menuju kurun waktu yang berkesenambungan antara masa lampau, masa sekarang, dan masa yang akan dating. Sejalan dengan itu Majid (2014: 8) mengemukakan bahwa sejarah adalah cabang ilmu pengetahuan yang mengkaji secara sistematis keseluruhan perkembangan, proses perubahan atau dinamika kehidupan masyarakat dengan aspek kehidupan yang terjadi di masa lampau. Masa lampau itu sendiri merupakan sebuah rangkaian kejadian yang sudah terlewati yang bersifat terbuka dan berkesinambungan. Sehingga sejarah merupakan keterhubungan dari apa yang terjadi dimasa lampau dengan gambaran dimasa sekarang untuk mencapai kehidupan yang lebih baik dimasa mendatang. 
E-ISSN: $2502-6674$

P-ISSN: 2502-6666

http://ojs.uho.ac.id/index.php/p_sejarah_uho

Sebagai konsekuensi dari tiga dimensi sejarah tesebut adalah terjadi suatu perubahan kearah perkembangan secara terhadap dalam aspek kehidupan manusia temaksud bidang ekonomi. Oleh karena itu dalam mengkaji aktivitas yang dilakukan oleh manusia pada masa lampau dalam usaha dalam mempertahan hidupnya dengan melakukan berbagai upaya yang lambat laun akan melahirkan suatu gaya hidup dan mata pencaharian masyarakat indonesia digolongkan sebagai masyarakat majemuk yaitu suatu masyarakat yang beraneka warna terdiri berbagai suku bangsa yang dipersatukan dalam wadah Negara Kesatuan Republik Indonesia dengan semboyan bineka tunggal ika artinya berbeda-beda tetap satu jua yang dipersatukan oleh Pancasila yang didalamnya terdapat sila Persatuan Indonesia.

Memahami kehidupan manusia, tidak lepas dari kehidupan masyarakat, karena didalamnya terdapat berbagai macam usaha yang di lakukan baik oleh individu maupun bersama-sama dengan individu-individu lainya. Begitu pula dalam kehidupan bermasyarakat akan di jumpai usaha untuk mempersatukan atau adanya pertentangan yang terjadi dalam masyarakat, tetapi yang penting dalam kehidupan dinamika masyarakat itu sendiri sebagai system sosial (Awan Mustakim, 2014: 25).

Pasar Wakuru yang lebih dikenal dengan nama Pasar Sentral Wakuru merupakan pusat aktivitas ekonomi masyarakat Wakuru Kabupaten Muna aktivitas yang terjadi di dalam kehidupan sehari-hari tidak terlepas dari pasar sebagai pusat interaksi masyarakat Wakuru. Pasar Wakuru merupakan salah satu pasar sentral terbesar di Tongkuno Kabupaten Muna, banyak hal dilakukan di Pasar Wakuru dari kebutuhan pangan, dan sandang. dengan mempunyai jadwal 3 hari, yaitu: hari Minggu, hari Rabu, dan hari Jumat. Hari Minggu merupakan hari yang paling ramai di Pasar Wakuru karena pedagang yang berjualan berdatangan dari daerah-daerah lain untuk berdagang di Pasar Wakuru dan pembeli dari daerah lain pun datang seperti Lombe, Metere, Lakapera, Lakudo, Kulidawa, Lapadindi, Bantea, Mento.

\section{METODE PENELITIAN}

Penelitian ini dilaksanakan di Wakuru Kecamatan Tongkuno Kabupaten Muna dengan menggunakan jenis penelitian sejarah yang bersifat deskriptif dengan mengunakan pendekatan kualitatif. Sumber yang digunakan dalam penelitian ini terbagi atas tiga kategori, yaitu: sumber tertulis, sumber lisan dan sumber visual. Prosedur pengumpulan data menggunakan metode sejarah yang dikemukakan oleh Sjamsuddin (2012: 17) yang terdiri dari heuristik (Pengumpulan Data) yang merupakan teknik pengumpulan data dengan melakukan penelitian kepustakaan, dan penelitian lapangan, penelitian lapangan dilakukan dengan pengamatan, wawancara dab studi dokumen. Setelah melakukan pengumpulan dilakukan tahap verivikasi data yangdilakukan dengan dua tahap yakni kritik (Verifikasi). Tahapa ini dilakukan dengan dua teknik yang melakukan kritik sumber yang berasal dari luar (eksternl) dan kritik sumber yang berasal dari dalam (intenal). Setelah itu dilajutkan kedalam tahapan histyoriografi dalam tahap ini dilakukan dengan 3 teknik yakni melakukan penafsiran data, melakukan penjelasan dan menyajikan data dalam bentuk karaya tulis.

\section{HASIL PENELITIAN DAN PEMBAHASAN \\ Sejarah Terbentuknya Pasar Sentral Wakuru}

Pembangunan pasar Wakuru tidak terlepas dari sejarah masyarakat yang ada di daerah ini dimana penduduk Kabupaten Muna khususnya masyarakat Wakuru dikuasai oleh Aruh Ndamani. Dia meruapakan seorang pengagas jalan yang menghubungkan Labasa, Wakuru sampai Lemoambo. Pada tahun 1960 Wakuru semakin bertambah dimana masyarakat hidup bercocok tanam jagung dan sayur-sayuran. Namun tahun 1961 masyarakat Wakuru mengeluh karena tanaman mereka banyak yang tidak tumbuh subur karena terpengaruh cuaca, dan kondisi geografis wilayah ini kekurangan air, sumber air dikampung ini sangat jauh dari tempat pemukiman sekitar $20 \mathrm{~km}$ dari tempat kami air La Ghontoe.

Masyarakat tersebut sudah mulai berinteraksi jual beli khususnya masyarakat Labhoora, Wongko dan masyarakat Lemoambo mereka ini membawa hasil pertanian berupa sayur-sayuran dan umbi-umbian untuk dijual di kampung lama tersebut transaksi pada waktu itu dilakukan pada 
E-ISSN: $2502-6674$

P-ISSN: 2502-6666

http://ojs.uho.ac.id/index.php/p_sejarah_uho

waktu 04.00 WITA sampai terbitnya matahari dan hasil penjualan tersebut digunakan untuk membeli kebutuhan pokok seperti minyak goreng, jagung dilakukan dengan cara barter di mana hasil pertanian ditukar dengan ikan.

Keadaan seperti itu kurang lebih sepuluh tahun lamanya baru dibangun Pasar Wakuru ketika berawal dengan adanya inisiatif beberapa warga masyarakat Lemoambo berupa membuka pasar darurat pada tahun 1977 melalui persetujuan pemerintahaan pada waktu itu ketika La Mbolo Lega jadi kepala desa di mana pasar tersebut ditempatkan di Desa Fongkaniua Kecamatan Tongkuno yang beribukota di Wakuru. Tidak lama kemudian pak La Mbolo Lega Meniggal dan digantikan oleh La Ode Kapala sebagai kepala desa. Dimasa pemerintahan La Ode Kapala pasar Wakuru dipindahkan di Desa Tombula beribukota di Wakuru tetapi lokasi dijadikan pasar sangat kacau hal ini disebabkan pemilik pertama lokasi sudah lama meninggalkan Kabupaten Muna.

\section{Fungsi Pasar Wakuru Bagi Kehidupan Masyarakat Wakuru Kecamatan Tongkuno dalam Bidang Perekonomian, Agama, Budaya dan Politik.}

\section{Sarana Transaksi Jual Beli}

Pasar merupakan wadah atau arenah saling bertemunya para penjual dan pembeli. Dalam bentuk yang sederhana, pasar berperan penting dalam memenuhi berbagai kebutuhan konsumen. Seperti masyarakat lainnya, penduduk kelurahan Wakuru Kecamatan Tongkuno mempunyai kebutuhan yang bersifat primer atau pokok dan sekunder atau kebutuhan tambahan. Sedangkan kebutuhan sekunder merupakan perlengkapan dari kebutuhan pokok. Yang dimaksud kebutuhan sekunder disini adalah barang-barang elektronik.

a. Kebutuhan Primer

Kebutuhan Pokok masyarakat kelurahan Wakuru hampir semuanya dibeli karena mereka tidak dapat memproduksi sendiri. Begitu Pula halnya para pedagang, bahkan kebutuhan pokok seperti: beras, minyak, kopi, the, sabun, sayur-sayuran dibeli untuk kemudian dijual lagi di pasar Wakuru. Namun ada juga beberapa kebutuhan pokok yang dapat mereka penuhi dari hasil produksi sendiri seperti, beras, kelapa, dan sayuran. Hal ini disebapkan karena sebagian besar penduduk Masyarakat Wakuru berprofesi sebagai petani. Meski demikian, kebutuhan pokok selain yang diproduksi sendiri, mereka memperoleh dengan cara membeli. Pasar Wakuru masyarakat dan pedagang dapat memenuhi kebutuhan pokok sehari-hari, disamping itu ada juga menjual obatobatan serta alat-alat bangunan, barang-barang tersebut cukup tersedia di Pasar wakuru

b. Kebutuhan Sekunder

Kebutuhan Tambahan Merupakan Kebutuhan yang tidak Mutlak harus ada, sebab tanpa kebutuhan barang-barang tersebut kehidupan tetap dapat berlangsung dengan baik, dapat dikatakan, kebutuhan sekunder dapat berupa barang-barang kebutuhan primer atau kebutuhan pokok yang dikembangkan dan ditingkatkan, baik jumlahnya atau kualitasnya.

Dalam hal kebutuhan sekunder ini nampaknya tidak mengarah kepada pengembangan kebutuhan pokok saja, melainkan berupa pakaian dan perumahan. Lebih jauh, untuk mendapatkan kehidupan lebih baik dan sempurna, manusia membutuhkan pendidikan, hiburan, perawatan, kesehatan, informasi dan sebagainya. Untuk memenuhi semua kebutuhan tersebut, kadangkala tidak bisa diperoleh di Pasar Wakuru saja melainkan diperoleh di Pasar Kota Bau-Bau-dan Makassar.

Barang kebutuhan sekunder yang disediakan di Pasar Wakuru adalah barang Perhiasaan, perabotan rumah tangga, barang-barang elektronik, seperti setrika, kipas angin, dan DVD atau VCD. Adapun barang elektronik seperti Televisi, kulkas, dan lainya merupakan sekunder yang cara memperolenya harus ketempat lain seperti Kekota Bau-Bau. Untuk kebutuhan sekolah berupa alat tulis dan buku umumnya dibeli di Pasar Wakuru, karena barang-barang tersebut cukup tersedia

Pemenuhan kebutuhan yang harus diperoleh sampai keluar kecamatan atau kabupaten, tidak menjadi masalah bagi masyarakat Wakuru Kecamatan Tongkuno. Hal ini disebabkan karena sarana dan prasarana transportasi cukup bagus, kondisi jalan dan pelabuhan yang baik serta alat angkutan berupa kendaraan. Adapun kendaraan dari wamengkoli menuju kekota Bau-Bau kendaraan yang digunakan kapal laut saja. Kemudahan transportasi ini memungkingkan 
E-ISSN: $2502-6674$

P-ISSN: 2502-6666

http://ojs.uho.ac.id/index.php/p_sejarah_uho masyarakat dapat berpergian ke Kota Bau- Bau dalam waktu singkat dan bisa kembali pada hari itu juga.

Dalam kegiatan yang berkaitan dengan pasar Wakuru barang-barang yang diperjualbelikan tidak hanya terbatas pada barang-barang keperluan sehari hari atau kebutuhan pokok saja. Seiring dengan perkembangannya pasar Wakuru juga menjual barang-barang modal yang dipergunakan dalam proses produksi oleh produsen. Produsen yang dimaksud ialah parah petani, pedagang dan nelayan.

Pembeli memanfaatkan Pasar Wakuru sebagai tempat untuk membeli barang-barang dagangan sesuai dengan kebutuhan mereka. Sudah barang tentu, sebagai tempat kegiatan ekonomi Pasar Wakuru akan melakukan aktifitasnya yang bersifat ekonomi. Dibidang produksi, Pasar Wakuru menyediakan kebutuhan modal dan hasil produksi. Untuk lebih jelasnya akan diuraikan sebagai berikut:

1) Modal

Dalam upaya menghasilkan sesuatu atau berproduksi, parah produsen sudah barang tentu akan membutuhkan modal untuk menunjang usaha mereka. Faktor penunjang yang lain yang tidak kalah pentingnya adalah peralatan. Maodal usaha dalam berproduksi tersebut dapat berupa modal dalam bentuk uang dan barang. Yang dimaksud modal uang disini adalah uang kontan yang dimiliki oleh parah produsen dan siap untuk diopersaikan. Sedangkan yang dimaksud dengan modal barang, dapat berupa barang yang tidak bergerak, dan barang bergerak. Barang yang tidak bergerak seperti tanah, atau los, sementara barang bergerak berupa sarana produksi.

Bagi pedagang Pasar Wakuru modal merupakan kunci utama berupa tempat untuk menjual seperti los, atau kios. Dari keterangan beberapa informan, ternyata modal mereka diperoleh dengan usaha sendiri seperti menjual kebun dan barang berharga lainya. Ada juga dengan cara mengumpulkan uang sedikit demi sedikit dan bahkan ada juga yang meminjam uang di bang. Adapun bagi parah petani, mereka memiliki peralatan pertanian, pupuk dan obat pemberantas hama. Serta memiliki sayur-sayuran serta mereka yang mempunyai kebun, kelapa, dan coklat.

Selain pedagang pasar ada juga pedagang kelontong dalam berproduksi memerlukan peralatan berupa lemari, rak-rak kayu yang dibeli atau dipesan dari tukang kayu. Bagi pedagang kain memerlukan alat pengukur dari kayu yang dibeli di Makassar. untuk pedagang makanan sehari-hari. Selain lemari, rak-rak kayu dan meja, juga memerlukan alat timbangan. Adapun yang diperlukan bagi pedagang nasi, makanan dan minuman sama dengan alat-alat rumah tangga seperti meja, bangku atau kursi, piring, gelas, sendok dan lain-lain. Umumnya alat-alat serta barang pecah belah mereka membeli dipasar Wakuru, kemudian peralatan pertanian untuk pengolahaan tanah seperti traktor di beli dimakasar, alat pertanian lainya seperti cangkul, sekop, parang dan sabit di beli dipasar Wakuru. Sedangkan alat pemberantasan hama atau seprayer mereka ada yang beli di Wakuru dan ada juga beli di Bau- Bau.

Daerah penelitian ini sudah banyak yang melakukan usaha peternakan secara besarbesaran melaingkan sebagai usaha sampingan. Ternak yang dipelihara adalah ayam,kambing,dan sapi. Peralatan untuk ternak ini adalah tali atau tambang serta kandang yang dibuat sendiri. Peralatan untuk ternak ayam adalah tempat makan ayam dan minum ayam, peralatan tersebut juga tersedia di pasar Wakuru.

2) Hasil Produksi

Hasil Produksi erat kaitanya dengan mata pencaharian penduduk. Adapun penduduk sekitaran Wakuru Kecamatan Tongkuno sebagain besar bermata pencaharian sebagai petani, perantau, dan pedagang. Bagi mereka yang berusaha dibidang pertanian tentu saja hasil yang diperoleh adalah berbagai hasil pertanian, antara lain sayur-sayuran, sedangakan mereka yang berusaha sebagai pedagang memperoleh keuntungan dalam bentuk uang tunai. Disamping itu adapula usaha lain yang mewarnai kehidupan, penduduk wakuru seperti peternak, pengrajin,dan penjual jasa. Hasil penting lainya adalah buah kelapa yang sudah dipetik biasanya langsung dijual, tetapi kebanyakan diolah dulu keudian baru dijual. Hasil lainya sayur-sayuran, cabe, dan umbiumbian.

Pedagang barang kebutuhan sehari-hari terutama took atau kios, meski barang dagangannya tidak dibuat sendiri melainkan dibeli ditempat lain, namun dapat menghasilkan 
E-ISSN: $2502-6674$

P-ISSN: 2502-6666

http://ojs.uho.ac.id/index.php/p_sejarah_uho

tersedianya barang kebutuhan pokok bagi masyarakat wakuru kecamatan tongkuno, para pedagang tersebut sangat besar perananya, lebih-lebih pada hari pecan (hari pasaran) masyarakat Wakuru kecamtan Tongkuno khusunya desa Tetangga pada hari pasaran dapat berbelanja kebutuhan pokonya seperti beras, gula, the, kopi, minyak goreng,agaram,sabun, dan lain-lain untuk peersediaan selama beberapa hari. Lain halnya dengan pedagang makanan, mereka menghasilkan makanan yang langsung dinikmati bagi konsumenya. Makanan yang dijual seperti, gado-gado,sup, bakso,nasi ikan, dan nasi ayam

\section{Sistem Distribusi}

Distribusi dapat diartikan sebagai proses penyebaran dan penyampaian barang kepada konsumen. Barang barang yang sudah diproduksi itu tidak ada gunanya sama sekali, kalau hanya tinggal tertimbun disiuatu tempat. Jadi barang-barang hasil produksi harus distribusikan kepada mereka yang membuntuhkan supaya dapat lebih bermakna dan lebih berguna. Oleh sebab itu aspek distribusi merupakan bagian yang erat kaitanya dengan aspek produksi dan aspek konsumsi. Kurang lancarnya pendistribusian suatu benda ekonomi akan mempengaruhi lanjutnya perkembangan produksi dan pada gilirannya akan mengurangi konsumsi. Dengan demikian aspek distribusi merupakan faktor penting dalam perekonomian suatu masyarakat. Distribusi dapat di laksanakan apabilah didukung olehsarana dan prasarana yang menunjung berlangsungnya proses distribusi. Sarana distribusi tersebut antara lain wadah, alat transportasi, dan jalan.

Ada dua jenis distribusi yang dilakukan di Pasar Wakuru yaitu bentuk distribusi langsung dan distribusi tidak langsung.

a. Distribusi Langsung

Bentuk distribusi langs ung terlaksana bila barang yang sudah diproduksi sampai ketangan konsumen tanpa melalui perantara atau pedagang. Dengan demikian barang-barang hasil produksi akan sampai ketangan konsumen langsung dari produsen. Dengan arti kata bahwa pendistribusian barang-barang tersebut di lakukan sendiri oleh parah produsen. Sebagai contoh dari distribusi langsung yang dapat ditemui di Pasar Wakuru adalah ketika pedagang makanan melayani pembeli. Dimana pendistribusianya dilakukan secara langsung kepada konsumen yang ingin menikmati masakan tersebut. Untuk usaha seperti ini, biasnya tidak dilakukan tawar menawar dalam harga.

\section{Distribusi tidak langsung}

Proses distribusi tidak langsung di mana hasil produksi dari tangan produsen ke tangan pihak tertentu sebagai perantara, untuk kemudian disebrkan kepada para pemakai atau yang membutuhkannya. Produsen menyalurkan barang kepada pedagang. Dari pedagang, hasil produksi dijual pada konsumen. Pembeli yang menjauh biasanya membeli barang dengan jumlah tertentu yang disesuaikan dengan jumlah pelanggan sedangkan konsuen yang beli dengan jumlah yang disesuaikan dengan kebutuahan pribadai dengan keluarga. Salah satu contoh dari distribusi tidak langsung yang dapat ditemui dipasar Wakuru ketika petani membawa hasil sayuranya ke pasar kemudian sayuran tersebut dibeli oleh pedagang sayur dan kemudian akan di jual lagi kepada konsumen. Dalam transaksi antara petani dengan pedagang biasanya terjadi tawar menawar sampai adanya kesepakatan

\section{Sarana Distribusis}

Sarana distribusi merupakan unsur yang sangat penting peranannya dalam proses penyebaran barang dagangan. Proses distribusi adalah segala sesuatu yang memungkingkan terjadinya proses penyebaran barang-barang dari produsen kepada konsumen secara lebih cepat. Sarana pendukung dalam sistem distribusi terdiri dari wadah, alat transportasi dan kondisi jalan.

Pasar Wakuru sebagai wadah atau tempat bertemunya penjual dan pembeli banyak peranya dibidang di stribusi dan konsumen dibandingkan dengan bidang produksi. Penduduk Wakuru Kecamatan Tongkuno dan desa tetangga banyak berdatangan di Pasar pada hari pasaran untuk berdagang. Hal ini dimanfaatkan oleh parah konsumen atau pembeli untuk membeli berbagai kebutuhanya.

Perkembangan dan kemajuan Pasar Wakuru tidak lepas dari sarana distribusi seperti alat transportasi untuk memindahkan barang dan penumpang dari suatu tempat ketempat lain. Sebagai alat angkut untuk memindahkan barang, maka alat tersebut sangat besar perananya dalam 
E-ISSN: $2502-6674$

P-ISSN: 2502-6666

http://ojs.uho.ac.id/index.php/p_sejarah_uho

menunjung perekonomian. Jenis alat angkut yang digunakan berupa kapal veriy, spid, kemudian diangkut lagi dengan sepeda motor, dan kendaraan roda empat. Pasar merupakan jantung kehidupan masyarakat Wakuru. Bagi masyarakat pedesaan kuhusunya masyarakat Wakuru pasar bukan sebagai kegiatan ekonomi, namun merupakan pintu masuk unsur-unsur kebudayaan dari luar daeranya. Pasar Wakuru merupakan arena pertemuan antara berbagai lapisan masyarakat yang akan saling terjadi interaksi. Melalui pasar, interaksi pasar bukan saja sesama warga masyarakar wakuru saja akan tetapi dengan warga desa tetangga. Disamping tukar menukar benda-benda hasil produksi, mereka saling berinteraksi, memberikan informasi dan berbaur antara satu dengan yang lainya.

Pasar Wakuru tidak hanya merupakan arena bertemunya pedagang dan pembeli, namun didalam pasar terjadi pula pertemuan antara pembeli dengan pembeli lainya. Para pembeli yang datang ke Pasar Wakuru tidak hanya berasal dari Kecamatan Tongkuno melaingkan dari desa tetangga. Pasar Wakuru yang hari pasaranya jatuh padah hari mingggu, rabu, jumat secara otomatis hanya ramai 3 kali dalam seminggu. Dalam pertemuan tersebut terjadi interaksi dan komunikasi bukan saja dalam masalah perdagangan dan jaul beli. Tidak jarang dalam pertemuan tersebut masing-masing menyampaikan berbagai pengalaman tentang hal-hal yang didengar, dilihat dan dialami ditempat lain, misalnya sebagai contoh ketika ada berita kematian atau pernikaahan maka dengan cepat berita terdengar dipasar. Sehingga hal tersebut menjadi sumber berita atau informasi bagai yang mendengarnya.

Jadi selain tempat arena bertemunya pedagang dan pembeli pasar berperan sebagai tempat untuk mendapatkan informasi. Pertemuan warga wakuru kecamatan tongkuno berlangsung. Setiap hari pasar padat tiap pekan yang relatif singkat dapat menjadi tempat bertemu parah sahabat. Menurut penduduk yang datang berbelanja ke Pasar Wakuru kebanyakan saling mengenal, dilihat dari tegur sapa mereka antara penduduk.

Hubungan antara penduduk desa yang kebetulan sering bertemu di pasar tidak hanya terbatas pada kempentingan ekonomi melaingkan hubungan yang berkembang menjadi hubungan yang bersifat kemsyarakatan. Hubungan mereka dikatakan cukup akrap walaupun kadang-kadang diantara mereka terdapat perbedaan status sosial dan suku. Diluar pasar hubugan penduduk desa dapat terlihat dalam kerja sama pada waktu mengatasi kesulitan keluarga atau musibah, mengadakan pesta dan sebagainya. Misalnya dalam musibah kematian parah ibu mempersiapkan kain kafan dan air bersih dan sebagainya sedangkan kaum laki-laki mengurus pemakaman seperti mencari keranda mayat dan menggali tempat untuk penguburan jenazah.

Sarana transportasi yang cukup memadai serta letak Pasar Wakuru yang bersampingan dengan luas jalan raya, banyak parah pedagang manapun pembeli yang datang dari luar desa. Pasar Wakuru merupakan tempat kegiatan ekonomi dan tempat pertemuan warga dari beberapa desa. Saat ini Pasar Wakuru sudah menjadi pertemuan yang dikunjungi oleh beberapa etnis. Dengan kata lain Penduduk Wakuru telah menampung suku Jawa, Medan, dan Bugis.

Pembeli di Pasar Wakuru tidak hanya satu suku bangsa. Disebapkan sering bertemu dalam kegiatan jual beli atau interaksi antara penjual dan pembli, terjalinlah hubungan yang akrab. Diantara mereka yang berlainanan jenis kebudayaan telah terjadi pembaruan. Pembaruan antara pembeli bukan hanya terjadi di pasar melaingkan dalam pergaulan sehari-hari adapun antara pedagang Pasar Wakuru telah terjadi hubungan yang cukup baik, dan kadang-kadang hubungan tersebut tidak hanya dalam kegiatan ekonomi saja. Menurut beberapa informan, sebagai besar hubungan baik antara pedagang dalam kegiatan berdagang ditentukan oleh hubungan yang menyangkut masalah pedagang, terutama yang masih sedaerah atau sesuku. Namun ada juga hubungan antar pedagang dalam kegiatan berdagan ditentukan oleh hubungan yang menyangkut masalah pedagang, terutama yang para pedagang masih sedeara atau sesuku. Namun ada juga hubungan antara pedagang yang tidak yang tidak didasari pada etnis atau suku tertentu, misalnya dalam kelompok arisan, yang dilakukan para pedagang tiap pekanya. Dimana setiap pedagang bisa ikut dalam kelompok arisan tersebut sangat membantu bagi pedagang yang kekurangan modal untuk mengembangkan usahanya.

Disisi lain Pasar Wakuru merupakan tempat untuk berkreasi dan mencari hiburan bagi masyarakat Wakuru dan sekitranya, Apalagi kelurahan belum tersedia sarana hiburan. Bagi 


\section{E-ISSN: $2502-6674$}

P-ISSN: 2502-6666

http://ojs.uho.ac.id/index.php/p_sejarah_uho

penduduk kelurahaan yang sehari-hari disibukan dengan pekerjaan di kebun, kantor, ataupun pergi ke Pasar pada hari pasaran merupakan hiburan. Disamping belanja mereka dapat berjalan-jalan melihat-lihat barang, meskipun tidak membeli. Untuk membedakan pengujung yang datang untuk belanja dan pengujung yang datang hanya sekedar untuk mencari hiburan dapat dilihat ketika pengujung tersebut datang kepasar untuk belanja namun jika sebaliknya pengujung tersebut dak membawah barang belanja maka pengujung tersebut datang kepasar hanya untuk mencari hiburan di pasar. Melihat keramaian pasar apalagi sambil menikmati makanan dan minuman tersedia menjadi hiburan tersendiri.

\section{Bidang Sosial Agama}

Agama adalah ajaran tentang nilai-nilai yang seharusnya dilakukan oleh manusia agar kehidupan mereka menemukan kebahagiaan didunia dan di akhirat dan sifatnya absolut kebenaranya yang bersumber dari wahyu, tuhan agama memerangkan dua fungsi. Pertama, menjelaskan suatu cekrawala pandang tentang dunia yang tidak terjangkau oleh manusia. Yang mengajarkan kesadaran terhadap pandangan dunia yang pada akhirnya melahirkan etos kerja sebagai balasan ideal yang akan diterima seseorang ketika berada di alam sesudah kebangkitanya. Kedua. Agama sebagai sarana ritual yang memungkinkan hubungan manusia dengan hal yang diluar jangkauannya.

Fungsi Pasar dalam bidang sosial agama adalah yang terjadi di Pasar Wakuru ini ada didalam menyangkut nilai agamanya ataupun yang menyangkut tentang agama hal ini dapat dilihat dari fungsi sebagai berikut:

1. Tempat bersilaturahim

Masyarakat Wakuru memiliki sifat yang terpuji baik dalam agama islam maupun non muslim. Bertemu, sama seperti saudara dan dengan sengaja untuk mengetahui kabar atau keadaannya adalah merupakan salah satu cara untuk mempererat hubungan antara sesama manusia itulah yang dimaksud dengan silaturahim dan itu sangat di anjurkan kepada umat islam, selain hubungan yang baik antara manusia dengan tuahannya (ALLAH) juga dianjurkan hubungan manusia dengan sesama manusia yaitu dengan saling peduli khusunya masyarakat Wakuru.

2. Tempat untuk bersedekah

Pasar dilihat dari bidang sosial Keagamaan dapat digunakan sebagai tempat bersedekah, hal ini terlihat dari fungsi Pasar Wakuru sebagai tempat untuk mengadakan penggalangan dana untuk orang banyak. Dengan memberikan sumbangan seseorang yang telah mendapatkan musibah seperti kematian, kecelakaan.

\section{Bidang Sosial Budaya}

Budaya suatu keseluruhan kompleks yang meliputi pengetahuaan,kepercayaan, kesenian, moral, keilmuan, hukum, adatistiadat, dan kemampuan lain serta kebiasaan yang didapat oleh masyarakat. Masyarakat Wakuru menjadikan kebudayaan merupakan wujud abstrak dari segala macam ide dan gagasan manusia yang bermunculan didalam masyarakat itu sendiri, baik dalam bentuk maupun berupa dalam system pengetahuaan, nilai, pandangan hidup, kepercayaan, presepsi, dan etos kepercayaan.

a. Gotong Royong

Merupakan cara kerja yang dilakukan oleh masyarakat Wakuru Kabupaten Muna secara beramai-ramai mengerjakan pekerjaan dan saling membantu untuk sebuah pekerjaan agar lebih mudah dan tidak mengharapkan materi yang berupa uang melaingkan berharap akan mendapatkan tenaga, sifatnya hanya menolong. Cara kerja bergotong royong ini sudah sejak lama dan sudah menjadi budaya bagi masyarakat Wakuru, khususnya Kabupaten Muna.

b. Tempat Hiburan

Hibuaran yang dimaksud sini bagi masyarakat Wakuru Kecamatan Tonggkuno Kabupaten Muna bertemu teman dan berbincang-bincang menikmati keramaian, banyaknya orang ke Pasar Wakuru ini mereka membuat kesenagan tersendiri mereka juga butu hiburan dan melihat orang yang jarang dilihat, dan suasana yang berbeda sehingga dapat menghilangkan rasah letih mereka yang sebagian besar bekerja pekerjaan yang kasar. Seperti, melihat barang jualan yang bagus, lhat asesoris yang cantik.

c. Tempat mencari informasi 


\section{E-ISSN: $2502-6674$}

P-ISSN: 2502-6666

http://ojs.uho.ac.id/index.php/p_sejarah_uho

Pasar sebagai tempat mencari informasi untuk sebagaian orang yang datang ke Pasar Wakuru hanya untuk berkumpul bersama teman-teman bercerita-cerita sambil menikmati makanan dan minuman mereka saling bertukar pengalaman dan kejadian masing masing, seperti tentang harga sayur sawit yang biasa mereka akan membandingkan toke sawit mana yang membeli sawitnya lebih mahal, dengan mengetahui harga pasaran sawit mereka bisa memprotes kenapa lebih murah dari yang lain, dengan begitu para toke itu tidak bisa memberi harga sawit di bawah pasaran.

d. Tempat mencari jodoh

Pasar Wakuru dilihat dari bidang sosial Budaya sebagai tempat mencari jodoh, muda mudi ke Pasar baik untuk berbelanja atau hanya untuk bermain saja selalu berhias diri supaya terlihat lebih cantik dan tampan, jika berjumpa orang yang di sukai terlihat lebih menarik, biasanya pada hari Minggu pemuda dan pemudi akan pergi ke pasar Wakuru sehingga lebih muda untuk mengetahuinya karena karena pada hari biasa perempuan-perempuan yang belum memiliki pasangan lebih banyak menghabiskan waktunya di rumah jarang keluar, pada hari Minggu inilah mereka keluar itupun karena pergi ke Pasar, inilah yang di manfaatkan oleh parah lelaki yang belum punya pacar.

\section{Bidang Sosial Politik}

Politik adalah seni untuk meraih kekuasaan yang sumbernya ideologi yang di perjuangkan. Dalam suatu proses sosial, perubahan kehidupan sosial di bidang politik dapat mempengaruhi kehidupan beragama. Pasar Wakuru merupakan suatu tempat untuk berpolitik yaitu di karenakan Pasar Wakuru tempat untuk orang berkumpul untuk suatu kepentingan masing-masing sehingga hal ini dilihat oleh parah politik atau orang yang mengharapkan dukungan dari masyarakat suatu peluang untuk meminta dukungan.

a. Tempat berkampanye

Kampanye adalah pengenalan atau pendekatan sesorang yang ingin mendapatkan dukungan dan suara dari masyarakat untuk suatu jabatan seperti Calaon Kepala Desa. Calon Anggota Legistatif dan Calon Jabatan lainnya. Cara mereka berkampanye sama dengan yang lainnya dengan membaur dan bertukar fikiran sama masyarakat yang mau mengeluarkan pendapat dan gagasan hal semacam ini sering disebut dengan blusukan, karena Pasar adalah dimana masyarakat berkumpul dan lebih mudah untuk mengambil simpati masyarakat Wakuru dan tidak membutuhkan biaya, waktu, dan kerja yang banyak untuk mengumpulkan masyarakat setempat sehingga mempermudah orang untuk berkampanye.

2. Tempat persaingan

Persaingan dalm Pasar Wakuru merupakan yang wajar, sudah biasa terjadi persaingan antara pedagang dan pedagang untuk menarik konsumen membeli barang dagangannya, konsumen dengan dagang pedagang dalam melakukan tawar menawar terjadi persaingan, konsumen ingin mendapatkan barang sesuai dengan harga yang diharapkannya. Contohnya seorang ibu ingin membeli baju untuk anaknya, pedagang member harga 70,000 dan ibu tersebut menawarnya dengan 50.000 tetapi pedagang tidak mau, dan mereka tawar-menawar hingga dapatlah kesepakatan si pedagang mendapat untug dan si ibu mendapatkan baju yang tidak terlalu mahal.

\section{Perkembangan Pasar Sentral Wakuru Kecamatan Tongkuno (1977-2017) Periode I. 1977-1979}

Pada tahun 1977 Pasar Wakuru dibangun awalnaya 40 x 40 meter yang terdiri dari 50 petak kios dengan sanggaran untuk membangun kios diambil dari swadaya masyarakat dan masih semi permanen karena dindingnya masih papan kayu dan beratap rumbia lantainya masih tanah. Pada tahun 1979 Pasar Wakuru mulai berkembang dari 50 petak kios itu setelah dirheap menjadi beberapa permanen karena dengan adanya partisipasi dan kerja sama masyarakat setempat dan membuat pondasi dengan susun batu karena penjualan mulai berkembang dan sebagai hasil jualan banyak hilang karena adanya pencuri yang meraja rela.

\section{Periode II. 1984-1993}

Pada tahun 1984 Pasar Wakuru berkembang lagi karena bangunanya ini bertambah dengan luas menjadi 70 x 80 meter dengan bertambahnya bangunan ini yang terdiri dari 3 los dan 48 kios 
E-ISSN: $2502-6674$

P-ISSN: 2502-6666

http://ojs.uho.ac.id/index.php/p_sejarah_uho

danah yang diajuh dari proposal yang pada saat itu sebagai camat Adhedhani. Karena beliau ini melihat keadaan Pasar Wakuru sangat cepat berkembanganya dengan banyaknya pedagang yang datang dari luar sehingga beliau ini membangun 3 los dan 48 kios untuk dikontrakan kepada penjual yang datang dari luar untuk di kontrakan kepada penjual yang datang dari luar untuk menjual di Pasar Wakuru. Pada tahun 1993 Pasar Wakuru bangunanya bertambah lagi menjadi 2 los dengan jumlah 52 kios dengan luas $120 \times 80$.

Pada tahun 2005 terjadi kebakaran di Pasar Sentral Wakuru pada ba'da shalat Magrib di mana kebakaran tersebut merupakan kejadian terbesar sepanjang sejarah di kawasan pusat perbelanjaan Pasar Wakuru Kecamatan Tongkun. Pasar Wakuru di pindahkan di Desa Lianosa, kemudian tahun 2005 dipindahkan kembali. Awalanya hanya enam bulan namun karna kondisi dan sesuatu hal perpindahan pasar tersebut tertunda selama 5 tahun. Pasca kebakaran pasar Wakuru mulai kembali aktif seperti sedia kala pada pertengahan Juni 2006. Pembangunan Pasar Wakuru pada tahun 2006 dianggarkan sebesar RP 4,5 M dengan rincian APBD II (DAU) sebesar Rp 3.509.450.000 serta Rp 990.550.000 juta dari APBD. Pada tahun 2008 pasar wakuru akan berakhir pembangunanya di mana pasar ini menela anggaran lebih 6 Miliyar

Pada tahun 2014 Pasar Wakuru mendapatkan bantuan dari PNPM-MP (Program Nasional Pemberdayaan Masyarakat-Mandiri Pedesaan) berupa 2 UNIT los termsuk 32 kios. Dua tahun kemudian Pasar Wakuru dibangun lagi dengan bantuan dari pemerintah pusat tepatnya oleh mentri perdagang yang bekerja sama dengan pemerintah Kabupaten Muna berupa 3 unit los dengan jumlah 45 petak dengan ukuran 3 x $4 \mathrm{~cm}$. Sekarang Luas Pasar Wakuru menjadi 170 x 90 Meter.

Barang dagangan yang dijual beragam seperti hasil laut (ikan dan cumi-cumi), hasil pertanian (sayu-sayuran, buah-buahan, merica, beras, dan kelapa), sarana produksi pertanian alatalat pertanian, pupuk dan pestsida) sembaki, dan alat-alat rumah tangga (pecah bela) dapat dijumpai di Pasar Wakuru sering dengan perkembnganya, di Pasar Wakuru sudah banyak jenis barang yang di perdgaangkan, tidak saja berasal dari desa tetangga akan tetapi barang dagangan bersal dari tempat yang jauh seperti Bau-Bau, Makasar berupa hasil pertanian dan alat sepeda motor dan elektronik, sepeda motor dan bahan bangunan. Untuk memperoleh gambaran yang lebih jelas tentang jenis-jenis barang yang dijual di Pasar Wakuru dan daerah asal barang dapat dilihat dalam table sebagai berikut:

Tabel Jenis Barang dan Daerah Asal Barang

\begin{tabular}{lll}
\hline No & \multicolumn{1}{c}{ Jenis Barang } & \multicolumn{1}{c}{ Daerah Asal Barang } \\
\hline $\mathbf{1}$ & Sayuran dan hasil pertanian & Fongkainiua, Walengkabola, Labhoora \\
$\mathbf{2}$ & Makanan & Matano oe, \\
$\mathbf{3}$ & Ikan & Wamengkoli, Mawasngka, \\
$\mathbf{4}$ & Sembako & Walengkabola \\
$\mathbf{5}$ & Mainan anak & Bau-Bau \\
$\mathbf{6}$ & Pecah belah & Bau-Bau \\
$\mathbf{7}$ & Kaset VCD/DVD & Bau-Bau \\
$\mathbf{8}$ & Sepatu dan sandal & Bau-Bau \\
$\mathbf{9}$ & Perlengkapan sekolah & Makasar \\
$\mathbf{1 0}$ & Pakaian & Makasar \\
$\mathbf{1 1}$ & Barang elektronik & Makasar \\
$\mathbf{1 2}$ & Sarana pertanian & Bau-Bau \\
& & Bau-Bau \\
\hline
\end{tabular}

(Sumber Data: diolah dari hasil penelitian, 2018)

Berdasarkan format di atas, menjelaskan bahwa hasil produksi dapat dijumpai di Pasar Wakuru Kecamatan Tongkuno desa Fongkainiua, Lambhoora, Walengkabola, Matano oe yang dijual di pasar berupa sayuran, hasil pertanian dan makanan. Ikan yang dijual di Pasar berasal dari Kecamatan Tongkuno yaitu Walengkabola dan Mawasangka, Wamengkoli. sering dengan 
E-ISSN: $2502-6674$

P-ISSN: 2502-6666

http://ojs.uho.ac.id/index.php/p_sejarah_uho

perkembnganya, sedangkan barang- barang seperti pakaian, barang elektronik sarana pertanian dan lain-lain bersal dari kota Bau-Bau, dan Makasar melalui jalur laut yang diangkut dengan kapal kayu khusus muatan barang exspedisi. Jadi hampir semua barang yang dijual di Pasar Wakuru berasal dari Kota Bau-Bau dan Makassar.

Sekarang sudah banyak pedagang yang berjualan di Pasar Wakuru pedagang yang berjualan di Pasar Wakuru tidak semuanya masyarakat Wakuru melaingkan ada juga pedagang yang berasal dari Kecamatan Tongkuno Selatan, kecamatan Parigi, Buton Tenggah, Kecamatan Bone, di mana Pasar tersebut letaknya yang cukup strategis yaitu terletak didekat jalan raya yang menghubungkan dengan Kecamatan Tongkuno Selatan dan Kecamatan Tongkuno, maka ketika hari pasar banyak pembeli yang berdatangan ke Pasar Wakuru untuk membeli kebutuhan yang diperlukan. Parah pembeli tersebut juga bukan hanya masyarakat Wakuru tetapi melaingkan juga warga desa tetangga pun ikut berdatangan ketika hari pasar. Seperti warga Desa Labasa, Desa Lawama, Desa Watondho, Desa Lianosa, Desa Kulidawa, Desa Wale-Ale, Desa Lapadindi, Desa Matanooe, Desa Lahontohe, Desa Fongkaniua, Desa Oempu, Desa Lamorende, Desa Lakologou, Tanjung, dan UP Wuna. Kelurahan Lawama, Kelurahan Danagoa, Kelurahan Tombula, Kelurahan Kontumolepe.

\section{PENUTUP}

Terbentuknya Pasar Sentral Wakuru Kecamatan Tongkuno Kabupaten Muna dilatarbelakangi oleh adanya inisiatif beberapa warga masyarakat Lemoambo untuk membuka pasar darurat pada tahun 1977 melalui persetujuaan pemerintah ketika La Mbolo Lega menjadi kepala desa pasar dibangun di Desa Fongkaniua Kecamatan Tongkuno Kabupaten Muna Tidak lama kemudian pak La Mbolo Lege Meninggal digantikan oleh La Ode Kapala sebagai kepala desa, pasar ini dipindahkan di Desa Tombula yang beribukota di Wakuru. Fungsi Pasar Wakuru merupakan wadah atau arena saling bertemunya para penjual dan pembeli. Dalam bentuk yang sederhana, pasar berperan penting dalam memenuhi berbagai kebutuhan konsumen. Seperti masyarakat lainnya, penduduk Masyarakat Wakuru Kecamatan Tongkuno mempunyai kebutuhan yang bersifat primer atau pokok dan sekunder atau kebutuhan tambahan. Sedangkan kebutuhan sekunder merupakan pelengkap dari kebutuhan pokok. Yang dimaksud kebutuhan sekunder disini adalah barang-barang elektronik. Fungsi Pasar dalam bidang sosial keagamaan yang terjadi di Pasar Wakuru adalah sebagai berikut: Pertama sebagai tempat bersilaturahim, antar masyarakat Desa Wakuru maupun di luar desa. Kedua sebagai tempat untuk dengan mengadakan penggalan dana untuk disumbangkan kepada keluarga yang ditimpa musibah seperti kematian dan kecelakaan

Perkembangan pada tahun 1977 Pasar Wakuru dibangun awalnaya 40 x 40 meter yang terdiri dari 50 petak kios, kemudian direncanakanh untuk dibangun lebih baik dengan biyaya dengan anggaran untuk membangun kios diambil dari swadaya masyarakat dan masih semi permanen karena dindingnya masih papan kayu dan beratap rumbia lantainya masih tanah. Pada tahun 1979 Wakuru mulai berkembang dengan pesat karena tadinya berjumlah 50 petak kios direhap menjadi permanen dan lebih besar karena dengan adanya partisipasi dan kerja sama masyarakat setempat untuk membuat pondasi dengan susun batu bata karena penjualan mulai berkembang dan sebagai hasil jualan banyak hilang karena adanya pencuri yang meraja rela.

\section{DAFTAR PUSTAKA}

Awan Mustakin. (2004). Dinamika Masyarakat Indonesia. Bandung: Eresco

Dibyo Harsono T. dkk, (1995), Dampak Pembangunan Ekonomi (Pasar)

Dien Majid, 2014. Ilmu Sejarah Sebuah Pengantar. Jakarta: Prenada Media Group.

Helius Sjamsuddin, (1996). Pengantar Ilmu Sejarah. Jakarta: Widya Sastra.

Soekarno dan Yustan Azidin, (1990). Peranan Pasar Pada masyarakat Pedesaan Daerah Kalimantan Selatann, Jakarta:Departemen Pendidikandan Kebudayaan

Syarifudin, dkk, (1990) Peranan Pasar Pada Masyarakat Pedesaan Daerah Kalimantan Selatan, Depdikbud, Jakarta 